(RESEARCH ARTICLE)

\title{
Comparative study of bioelectricity generation by microbial degradation of organic wastes using microbial fuel cell
}

\author{
Thenmozhi M, Hooreen D, Sowmiya V and Dhasarathan $\mathrm{P}^{*}$ \\ Department of Biotechnology, Prathyusha Engineering College, Chennai - 602 025, Tamilnadu, India.
}

Publication history: Received on 28 May 2020; revised on 07 June 2020; accepted on 09 June 2020

Article DOI: https://doi.org/10.30574/wjarr.2020.6.3.0178

\begin{abstract}
In the present project, we investigate to generate bioelectricity from organic wastes such as Citrus sinensis peel slurry and Oryza sativa waste water and characterize the electrogenic bacteria responsible for the generation of bioelectricity. The maximum voltage of about $0.8 \mathrm{~V}$ was generated from Citrus sinensis peel slurry in 16 days, whereas $0.642 \mathrm{~V}$ was generated in a period of 14 days from Oryza sativa waste water. In series connection of microbial fuel cells, voltage of $2.850 \mathrm{~V}$ was measured. Four electrogenic bacterial isolates were obtained from the anode of microbial fuel cell and various biochemical characterization tests were performed. The effect of addition of different concentrations of glucose to the anode chamber of microbial fuel cell along with the organic wastes was analysed and $3 \mathrm{~g} / \mathrm{l}$ was found to be the optimum glucose concentration to increase the performance of microbial fuel cell. The output from the microbial fuel cells can be implemented to power low power consuming devices and biosensors.
\end{abstract}

Keywords: Bioelectricity; Microbial fuel cell; Electrogenic bacteria; Citrus sinensis peels; Oryza sativa waste water.

\section{Introduction}

Nowadays the world is observing an energy crisis due to huge energy demand and limited resources. Combustion of non-renewable energy emits a lot of greenhouse gas like carbon dioxide, which has shown alarming consequences to the environment [1]. An alternative strategy is direct conversion of sugars to electrical power [2]. Microbial fuel cells (MFCs) are emerging as promising technology for the treatment of wastewaters [3]. Microbial fuel cells (MFCs) directly convert biodegradable substrates to electricity and carry good potential for energy- positive waste water treatment [4]. Microbial fuel cells (MFCs) are devices that can use bacterial metabolism to produce an electrical current from a wide range organic substrate [5]. Recently great attentions have been paid to microbial fuel cells (MFCs) due to their mild operating conditions and using variety of biodegradable substrates as fuel [6]. The added advantage of using MFC technology for different effluent treatment is that several bio-based processes include removal of biochemical and chemical oxygen demand, nitrification, denitrification sulphate removal and removal of heavy metals can be carried out in the same bioreactor [7]. A typical MFC consists of anode and cathode compartments, which are separated by a cationic proton exchange membrane. Salt-bridge is the economic alternative to highly priced proton exchange membrane in the construction of a microbial fuel cell [8]. To improve the performance of microbial fuel cells (MFCs), the biocathode electrode material of double-chamber was optimized [9]. For practical applications of MFC technology, the design as well as the process of manufacturing and assembly, should be optimized for the specific target use [10]. A number of microorganisms having electricity generating efficiency such as Geothrix species and Shewanella, can produce their own electron shuttles. Geobacter species are advantageous due to the presence of the ability to directly transfer electrons to electrodes, when competing for space on the anode of sediment microbial fuel cells [11]. Shewanella oneidensis is able to conserve energy for growth by reducing a wide variety of terminal electron acceptors during anaerobic respiration, including several environmentally hazardous pollutants [12].

\footnotetext{
${ }^{*}$ Corresponding author: Dhasarathan $\mathrm{P}$
} 
The main objectives of this study were to generate bioelectricity from the two different organic wastes including Citrus sinensis peels and Oryza sativa waste water and to biochemically characterize the electrogenic bacterial isolates. Also, to optimize the effect of addition of glucose for enhancement of MFC performance.

\section{Material and methods}

\subsection{Sample collection}

The substrates for bioelectricity generation, Citrus sinensis peels and Oryza sativa waste water were collected from the domestic kitchen waste in a sterile plastic container and converted into slurry with a concentration of $50 \mathrm{mg} / \mathrm{ml}$. The soil sample was collected near juice shop of Prathyusha Engineering College, Chennai-602025, in aseptic manner for isolation of bacteria from soil.

\subsection{Fabrication of microbial fuel cell setup}

The H-type microbial fuel cell was constructed by connecting the anode and cathode compartments with a salt bridge composed of $5 \%$ sodium chloride and $5 \%$ agar. The anode was made up of zinc electrode whereas the cathode was made up of aluminum electrode with a dimension of $100 \mathrm{~mm} * 25 \mathrm{~mm}$.

\subsection{Preparation of mixed culture}

The mixed culture was prepared by adding $1 \mathrm{~g}$ of soil to $250 \mathrm{ml}$ of sterile nutrient broth. It was incubated at $37^{\circ} \mathrm{C}$ for 24 hours and used as inoculum for microbial fuel cell.

\subsection{Loading of samples and measurement of voltage from MFC}

Citrus sinensis peel waste and Oryza sativa waste water was loaded into the anode compartment of different MFCs and $0.1 \mathrm{M}$ phosphate buffer was added into the cathode compartment. The electrodes were inserted into the respective compartments. The mixed culture was inoculated into the anode compartment. The voltage generated from the microbial fuel cell was measured periodically using a digital multimeter FLUKE 17B.

\subsection{Isolation of electrogenic bacteria from MFC}

After a period of about 45 days, the enriched and pre acclimatized electrogenic bacteria capable of producing bioelectricity were isolated from the biofilm on the surface of anode of microbial fuel cells. The bacterial suspension was serially diluted up to $10^{-12}$ dilutions and spread plates technique was carried out. Then, the number of bacterial colonies were counted. The quadrant streak technique was performed to obtain pure bacterial isolates, which were inoculated on surface of the slant and incubated at $37^{\circ} \mathrm{C}$ for 24 hours.

\subsection{Biochemical characterization}

The various biochemical characterization tests such as Gram's staining, hanging drop technique, citrate utilization test, catalase test, urease test and sulphide indole motility test was performed for all the electrogenic bacterial isolates HST1, HST2, HST3 and HST4. The confirmatory test using King B agar medium was carried out to identify the electrogenic bacterial isolates.

\subsection{Effect of different glucose concentrations in anode compartment}

The glucose was added in three different concentrations including $1 \mathrm{mg} / \mathrm{ml}, 3 \mathrm{mg} / \mathrm{ml}$ and $5 \mathrm{mg} / \mathrm{ml}$ along with the organic waste into the anode chamber to optimize and enhance the performance of microbial fuel cell and the generated voltage was measured.

\section{Results and discussion}

The organic wastes includingCitrus sinensis peels and Oryza sativa waste water was collected from the domestic kitchen waste in a sterile plastic container. The final concentration of both the organic samples was $50 \mathrm{mg} / \mathrm{ml}$. The mixed culture of bacteria from soil was inoculated into the anode chamber of microbial fuel cell. The voltage was generated from the microbial fuel cell by the degradation of Oryza sativa waste water and Citrus sinensis peel waste. The generated voltage was measured using a digital multimeter for 30 days (figure 1). 

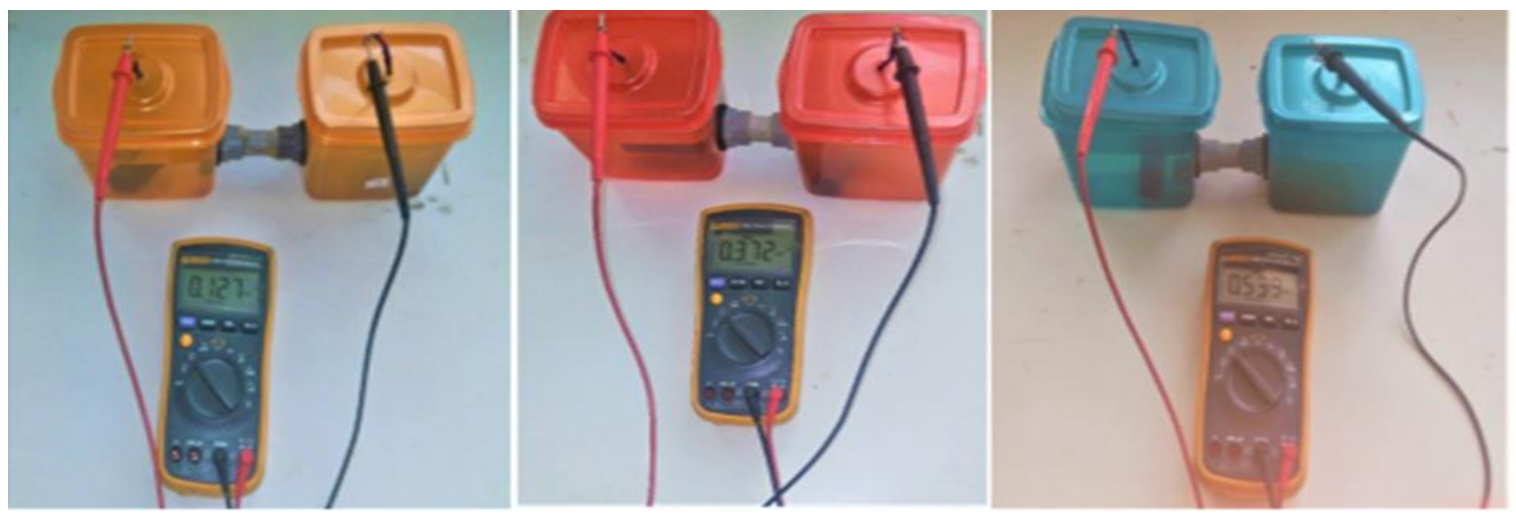

Figure 1 Voltage measurement for glucose optimization using digital multimeter

A stable voltage was recorded for 10 days from Citrus sinensis peel waste slurry. The maximum voltage of $0.8 \mathrm{~V}$ was measured from Citrus sinensis peel waste inoculated with mixed culture. The generation of bioelectricity was low from Citrus sinensis peel wastewithout inoculation (figure 2).

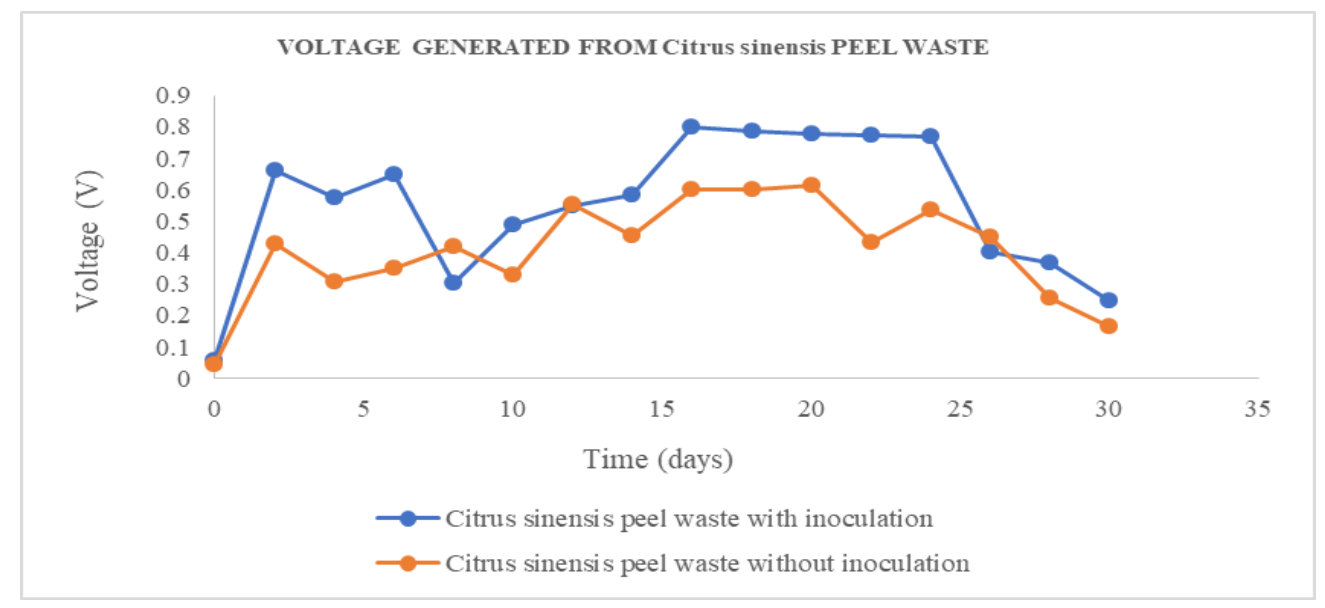

Figure 2 Effect of inoculation on voltage generation from Citrus sinensis peel waste

A stable voltage was recorded for 14 days from Oryza sativa waste water. The maximum voltage of $0.642 \mathrm{~V}$ was measured from Oryza sativa waste waterinoculated with mixed culture.

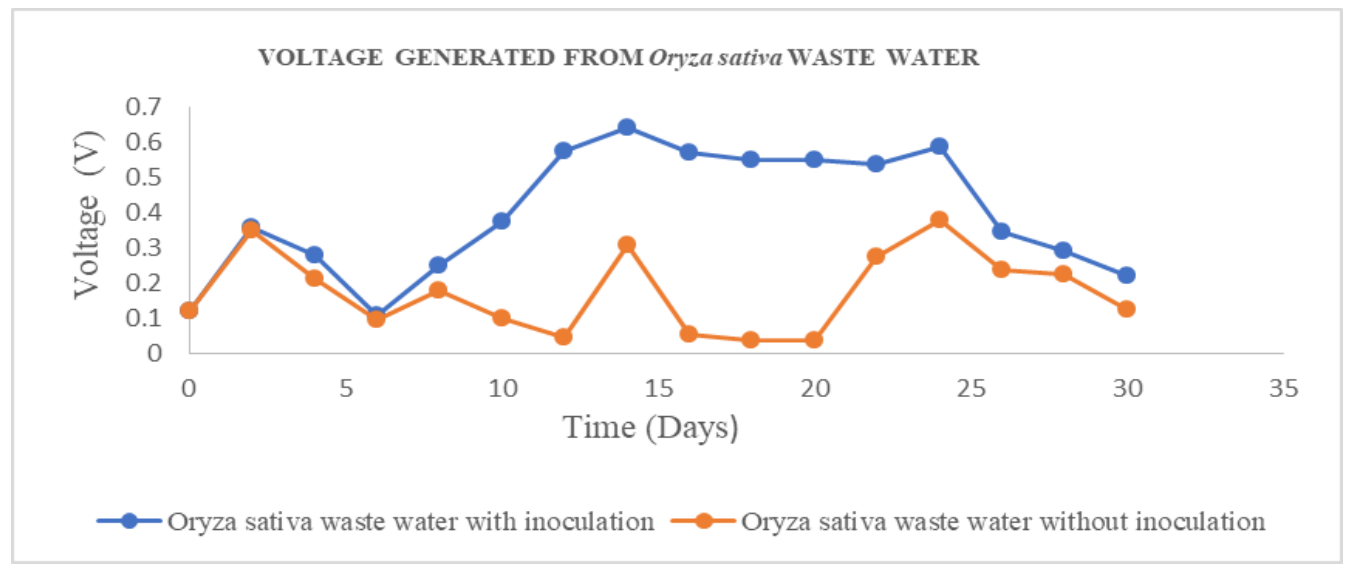

Figure 3 Effect of inoculation on voltage generation from Oryza sativa waste water 
Itwas observed that there was fluctuation in the voltage generation in the initial period and then there was increase in voltage generation. In series connection, a stable voltage obtained was $2.5 \pm 0.3 \mathrm{~V}$. A maximum of $2.8 \mathrm{~V}$ was produced from four microbial fuel cells in series connection (figure 4).

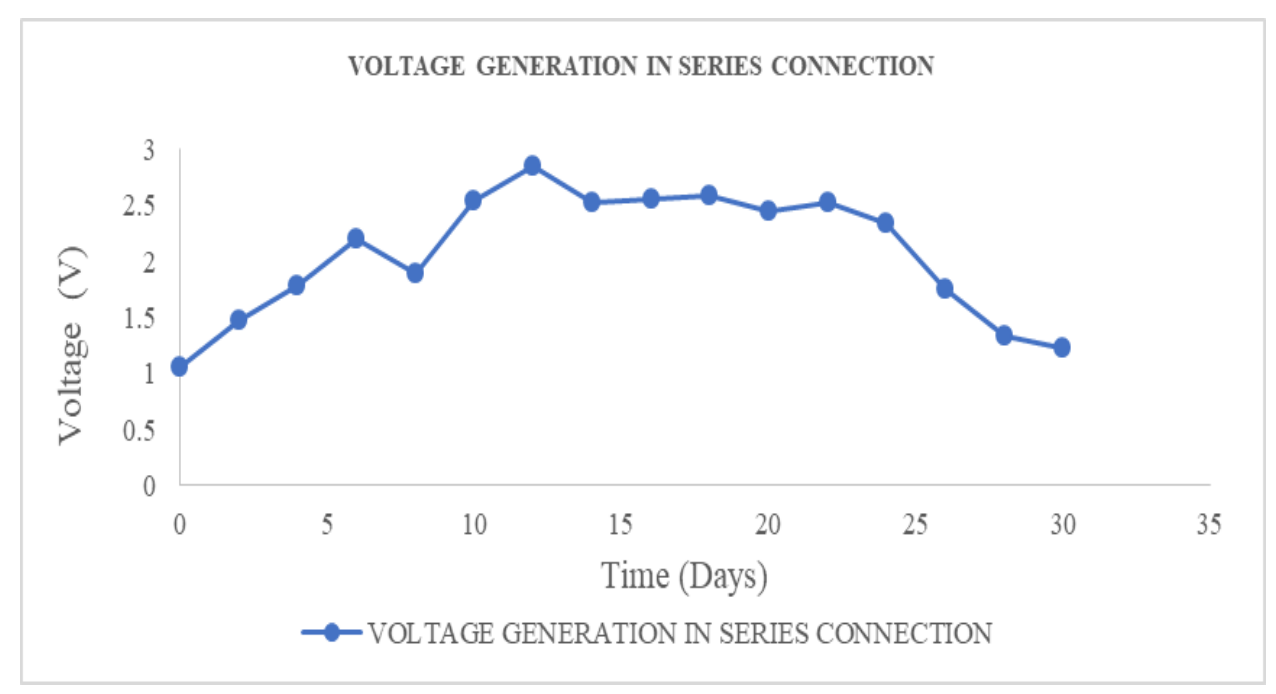

Figure 4 Generation of voltage from four microbial fuel cells connected in series.

A total of four enriched electrogenic bacteria were isolated by nutrient agar from the biofilm on the surface of anode of Oryza sativa waste water and Citrus sinensis peel slurry microbial fuel cells (figure 5). These isolated bacterial strains were named as HST 1, HST 2, HST 3 and HST 4. The morphology of the bacterial colonies such as colour, shape, size, opacity, elevation and texture were observed and noted (table 1). The quadrant streak plate technique was performed (figure 6).
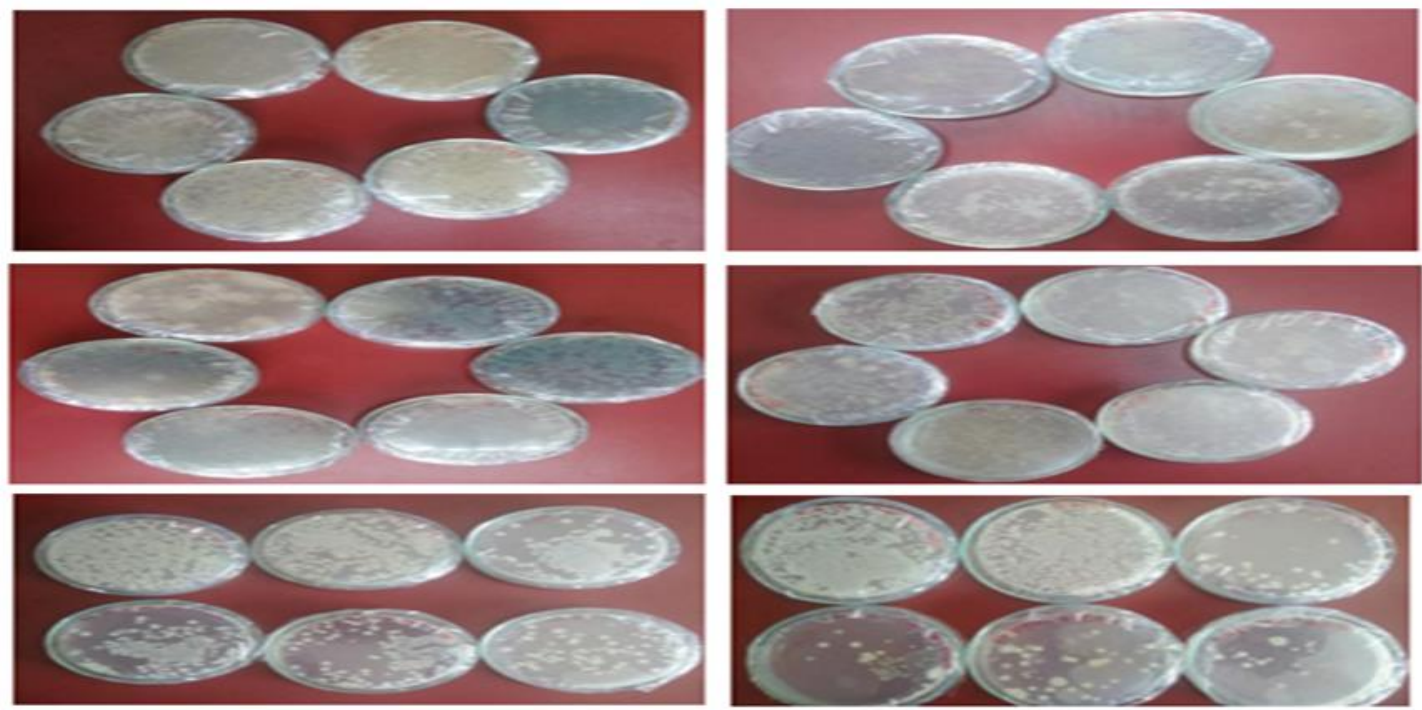

Figure 5 Enumeration of electrogenic bacterial isolates from different samples 
Table 1 Colony morphology of the electrogenic bacterial isolates

\begin{tabular}{lllll}
\hline CHARACTERISTICS & HST 1 & HST 2 & HST 3 & HST 4 \\
\hline Colour & Orange & yellow & white & white \\
Shape & circular & circular & circular & filamentous \\
Size (mm in diameter) & 3 & 4 & 3 & 5 \\
Optical property & transparent & opaque & opaque & opaque \\
Elevation & flat & raised & raised & flat \\
Texture & sticky & sticky & sticky & sticky \\
\hline & & & & \\
\end{tabular}

Figure 6 Quadrant streak plates of electrogenic bacterial isolates

All the four electrogenic bacterial isolates HST 1, HST 2, HST 3 and HST 4 were biochemically characterized. Gram's staining, hanging drop technique, citrate utilization test, catalase test, urease test and sulphide indole motility test was performed (table 2).

Table 2 Various biochemical characterization tests for electrogenic bacteria

\begin{tabular}{llllll}
\hline S.NO & $\begin{array}{l}\text { BIOCHEMICAL } \\
\text { TEST }\end{array}$ & HST1 & HST2 & HST3 & HST4 \\
\hline 1 & gram staining & $\begin{array}{l}\text { gram } \\
\text { negative(rod) }\end{array}$ & $\begin{array}{l}\text { gram } \\
\text { negative(rod) }\end{array}$ & $\begin{array}{l}\text { gram } \\
\text { negative(rod) }\end{array}$ & $\begin{array}{l}\text { gram } \\
\text { positive (rod) }\end{array}$ \\
2 & catalase test & positive & positive & negative & positive \\
3 & urease test & negative & positive & negative & negative \\
4 & motility test & positive & positive & positive & negative \\
5 & indole test & positive & positive & positive & negative \\
6 & H2S production & positive & positive & negative & negative \\
7 & citrate test & positive & positive & negative & positive \\
\hline
\end{tabular}


It confirmed that HST1 electrogenic bacterial isolate was Pseudomonas $s p$ by the appearance of fluorescent greenish yellow colour in the King B agar plate containing HST1 bacterial isolate (figure 7).The yellow colour was not produced by the remaining bacterial isolates.

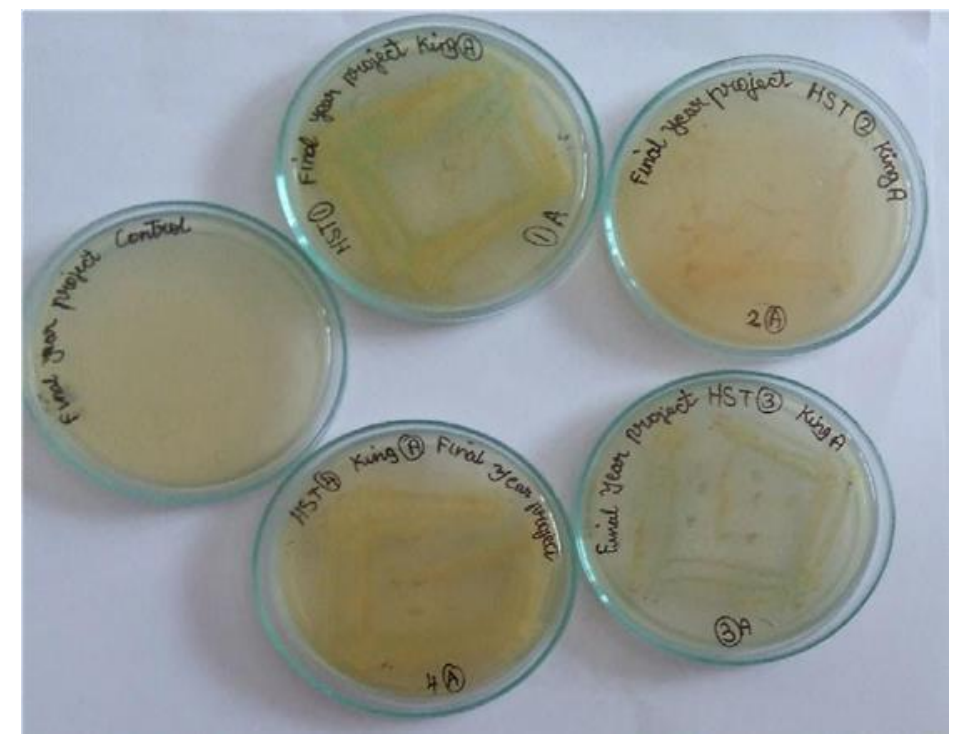

Figure 7 Electrogenic bacterial isolates on King B agar plates

The performance of microbial fuel cell was analyzed by the addition of glucose into the anode chamber of microbial fuel cell along with the substrates Citrus sinensis peel waste and Oryza sativa waste water. It was observed that $3 \mathrm{mg} / \mathrm{ml}$ of glucose concentration had maximum effect on voltage generation due to the enhanced activity of electrogenic bacteria.The stable voltage was generated for 5 days form Oryza sativa waste water (figure 8) and 3 days from Citrus sinensis peel waste (figure 9).

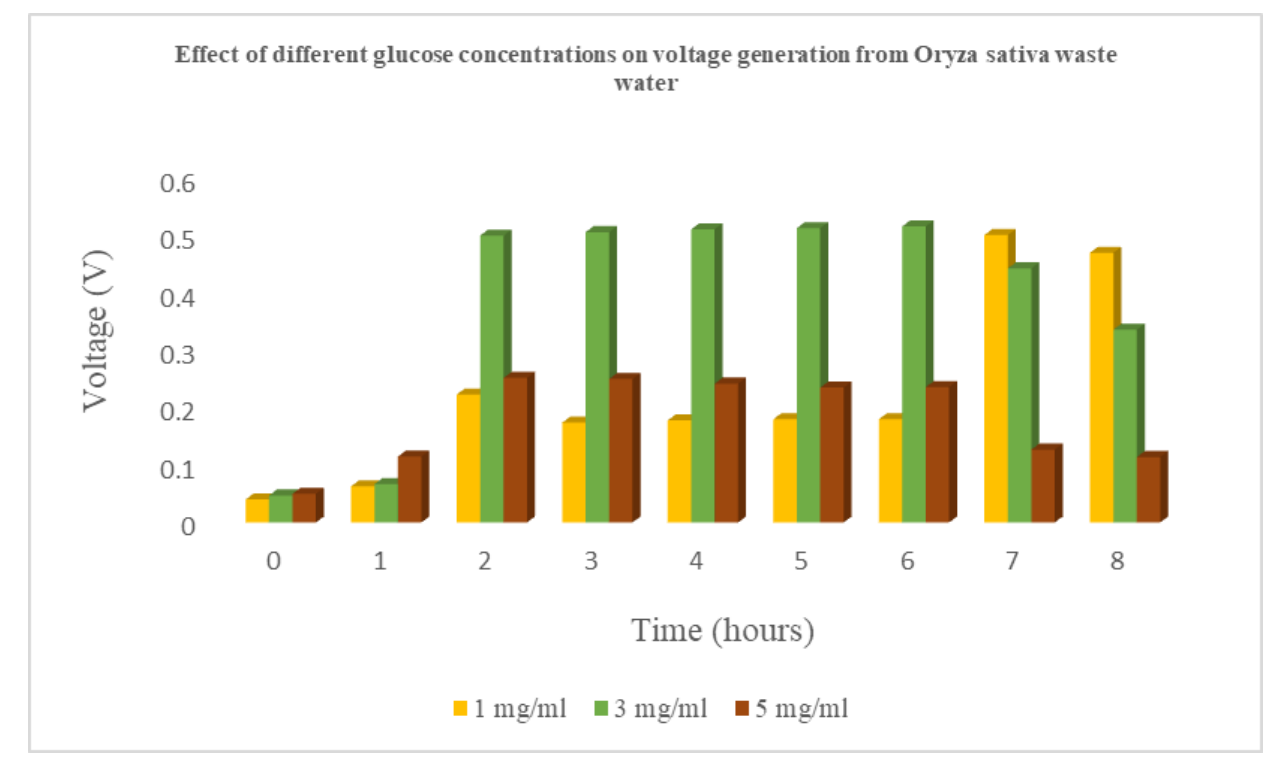

Figure 8 Effect of different glucose concentrations on voltage generation from Oryza sativa waste water 


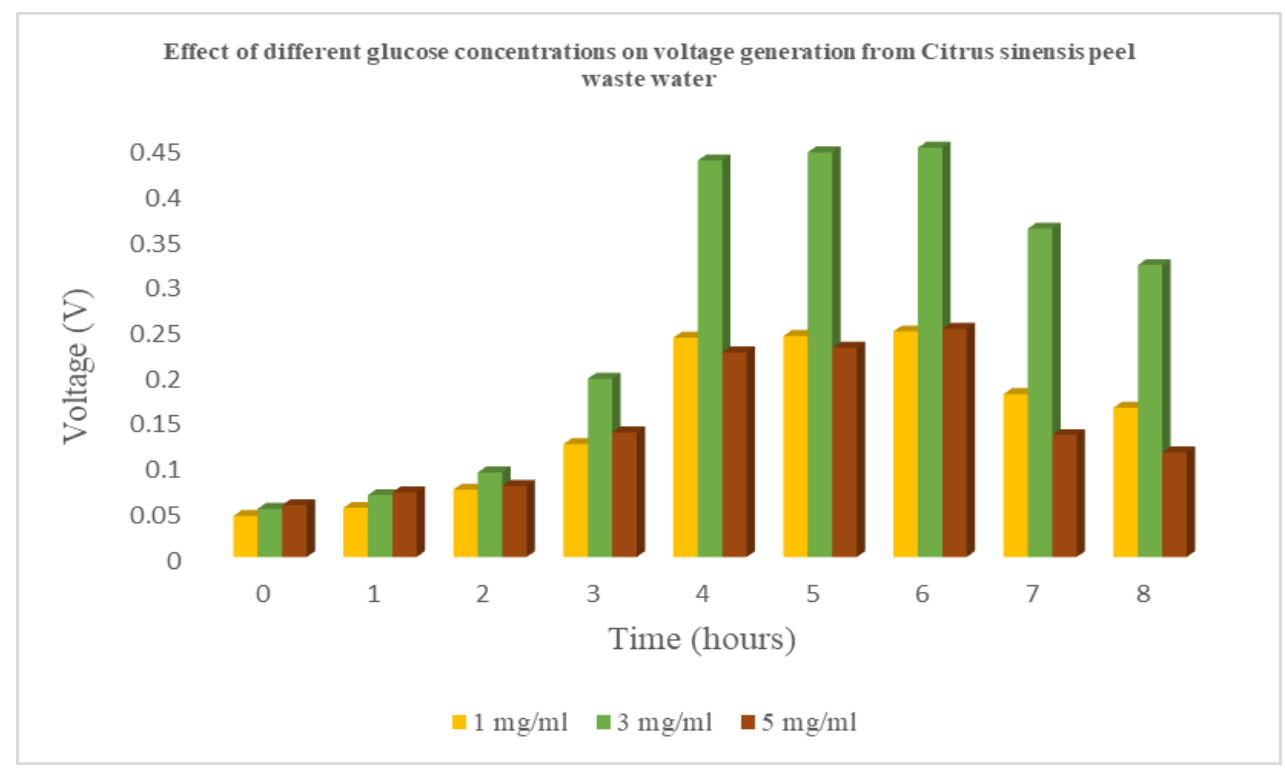

Figure 9 Effect of different glucose concentrations on voltage generation from Citrus sinensis peel waste water

According to the previous reports, Washington Logrono et al., [13] demonstrated the bioelectricity generation from vegetable and fruit wastes with high Andean soil as microbiological resources and reported the highest value of output voltage of $330 \mathrm{mV}$ over a testing period of 60 days by the activity of electrogenic microorganisms. Elviliana et al., [14] analyzed the generation of bioelectricity from banana and orange peel waste using microbial fuel cells. The cathode was perforated copper plates coated with activated carbon powder and anode consisted of zinc plates coated with graphite powder. The voltage and current were measured for 10 days and the highest reported was $0.492 \mathrm{~V}$ and $0.101 \mathrm{~mA}$ for banana peel waste and $0.563 \mathrm{~V}$ and $0.017 \mathrm{~mA}$ for orange peel waste respectively. The study concluded that the organic content of substrates and the microbial activity influenced the electricity production from the MFCs.

\section{Conclusion}

The maximum voltage was generated from Citrus sinensis peel slurry compared to Oryza sativa waste water sample using double chamber microbial fuel cell. The electrogenic bacteria were isolated from MFC and biochemically characterized. The performance of MFC was enhanced by optimizing the addition of glucose along with substrates into MFC.

\section{Compliance with ethical standards}

\section{Acknowledgments}

Authors are extremely thankful to the management and Department of Biotechnology of Prathyusha Engineering College, Chennai for providing opportunity, support, guidance and well-equipped laboratories facilities required for successful completion of the present project work.

\section{Disclosure of conflict of interest}

The authors do not disclose any conflict of interest.

\section{References}

[1] Anthony JS, Kathryn A, Whitehead, Dale AC and Brownson Craig E, Banks. (2019). Microbial fuel cells: An overview of current technology. Renewable and Sustainable Energy Reviews, 101, 60-81.

[2] Swades K, Chaudhuri and Derek R Lovley. (2003). Electricity generation by direct oxidation of glucose in mediatorless microbial fuel cells. Nature biotechnology, 21(10), 1229-1232.

[3] Aelterman P, Rabaey K, Clauwaert P and Verstraete W. (2006). Microbial fuel cells for wastewater treatment. Water Science and Technology, 54(8), 9-15. 
[4] Fernanda LL, Heming W, Casey F and Zhiyong JR. (2015). AC power generation from Microbial fuel cells. Journal of power sources, 297, 252-259.

[5] Ashley E, Franksand Kelly P and Nevin. (2010). Microbial fuel cells, A current review. Energies, 3(5), $899-919$.

[6] Rahimnejad M, Adhami A, Darvari S and Zirepour A. (2015). Microbial fuel cell as new technology for bioelectricity generation: a review, American Economic Journal, 54(3), 745-56.

[7] Elviliana, Toding OSL, Virginia C and Suhartini S. (2018). Conversion of banana and orange peel waste into bioelectricity using fuel cell. Earth and Environmental Science, 209, 1-5.

[8] Hairti T, Rui L, Jing L, Rashid A, Xiaohui W, Yanmei G and Yuan L. (2016). Carbon material optimized for improving microbial fuel cell performance. Front microbiol, 7(6), 1-9.

[9] Hui W, Katherine H, Roger M, Jarvis, Jonathan R, Lloyd and Royston G. (2010). Phenotypic Characterization of Shewanella oneidensis MR-1 under Aerobic and Anaerobic Growth Conditions by Using Fourier Transform Infrared Spectroscopy and High-Performance Liquid Chromatography Analyses, Applied and Environmental microbiology, 76(18),6266-6276.

[10] Jiseon Y, Richard J, Preen, Larry B, John G and Ionnis I. (2017).3D printed components of microbial fuel cells: Towards monolithic microbial fuel cell fabrication using additive layer manufacturing, Sustainable Energy Technologies and assessments, 19, 94-101.

[11] Ramya Nair, Renganathan K, Barathi S and Venkataramanan k. (2013). Performance of salt bridge microbial fuel cell at various concentrations using hostel sewage as substrate. International Journal of Advancements in Research and Technology, 2(5), 326-330.

[12] Smita SK, Vivek K, Sandeep K, Malyan, Jyoti S, Thangavel M, Marshal S, Maskarenj, Prakash C, Ghosh and Arivalagan P. (2019). Microbial fuel cells (MFCs) for bio electrochemical treatment of different wastewater streams. Fuel, 254(115526), 1-36.

[13] Washington L, Geovany R, Celso R, Magdy E and Ana C. (2015). Bioelectricity generation from Vegetables and fruit wastes by using single chamber microbial fuel cells with high Andean soils. Energy Procedia, 75.

[14] Yujin C, Hui M, Wei L, Rubing Z, Jing G, Mo X and Huizhou L. (2019). Electrogens in the anode of microbial fuel cells: pure cultures versus mixed communities. Microb Cell Fact, 18(39), 1-14.

\section{How to cite this article}

Thenmozhi M, Hooreen D, Sowmiya V and Dhasarathan P. (2020). Comparative study of bioelectricity generation by microbial degradation of organic wastes using microbial fuel cell. World Journal of Advanced Research and Reviews, $6(3), 35-42$. 